\title{
Pharmacogenetics of Antidepressant Drugs: An Update
}

\author{
Concetta Crisafulli ${ }^{1}$, Antonio Drago ${ }^{2,3}$, Marco Calabrò $^{1,4}$, \\ Antonina Sidoti ${ }^{1}$, Alessandro Serretti ${ }^{2}$, Edoardo Spina ${ }^{4}$ \\ ${ }^{1}$ Department of Biomedical Science and Morphological and Functional Images, \\ University of Messina, Messina, Italy; \\ 2 Department of Biomedical and Neuromotor Sciences - DIBINEM, University of Bologna, \\ Bologna, Italy; \\ ${ }^{3}$ I.R.C.C.S. "San Giovanni di Dio", Fatebenefratelli, Brescia, Italy; \\ ${ }^{4}$ Department of Clinical and Experimental Medicine, University of Messina, Messina, Italy
}

\section{SUMMARY}

Pharmacological treatment of depressive disorders is characterized by poor predictability of individual response. In recent years, the increasing evidence has demonstrated that genetic factors play a critical role in determining the differences in treatment outcome to antidepressant drugs. A number of pharmacogenetic studies on antidepressant drugs has been conducted, and genetic variations at level of drug metabolizing enzymes, drug transporters and drug targets, possibly influencing the clinical response, have been identified. Pharmacogenetics may hopefully provide the basis for individualized pharmacotherapy of depressive disorders in order to maximize the probability of a favorable response and minimize the risk of adverse drug reactions. In this article, the major findings related to the pharmacogenetics of genes involved in the pharmacokinetics and pharmacodynamics of antidepressant drugs are critically reviewed.

Keywords: pharmacogenetics; antidepressants; gene; depression

\section{INTRODUCTION}

Major Depressive Disorder (MDD) is a complex and highly prevalent psychiatric disorder that is usually manifested with the episodes of low mood generally accompanied by low self-esteem and generalized loss of interest for any activity. This debilitating condition has a severe impact on quality of life-social relationship and psychological state that has been shown to be at least equal if not greater than other major chronic medical conditions (arthritis, diabe- tes, heart disease) $[1,2,3]$. According to World Health Organization (WHO), MDD will be the second leading cause of death and disability worldwide by 2020 among people between 15-44 years $[4,5]$.

Unfortunately, depressed patients are not totally satisfied with the current effectiveness and tolerance of the available antidepressant drugs (ADs). Many clinical studies have shown that about $30 \%-40 \%$ of the MDD individuals fail to respond to the first treatment [6], and even after several trials around $30 \%$ of patients 
do not fully recover from depressive disorder [7]. Treatment resistant depression (TRD) is an extremely common problem, affecting a large proportion of all patients suffering from $\operatorname{MDD}[8,9]$. Moreover, adverse drug reactions (ADR) also have to be considered when selecting antidepressant treatment. In fact, ADRs are major causes of non-adherence and non-compliance to treatment. Given the high frequency of ADRs, the American College of Physicians recommends that the selection of an antidepressant should be based on ADR profiles, cost and patient preferences [10]. The main reason for this is still incomplete knowledge of the pathophysiologic basis of depression and the mechanism of action of ADs.

The increasing evidence has demonstrated that genetic factors play a critical role in the variation of treatment response $[5,11,12]$. For this reason, one of the most important and promising aspect of medicine is the personalization of therapy. It may be achieved by adapting the therapy to individual patient by means of genetic and other molecular tools. Pharmacogenetic studies suggest that single nucleotide polymorphisms (SNPs) can be used in clinical association studies to determine the contribution of genetic variance in drug response. Moreover, associating novel candidate genes with antidepressant response may lead to the development of a new class of medications $[13,14,15]$. In recent years, the development of pharmacogenetics has provided more opportunities for individualized pharmacotherapy of depressive disorders [15]. So far, most pharmacogenetics studies have investigated genes involved in the pharmacokinetics and pharmacodynamics of ADs [15]. Several genetic variations at level of drug metabolizing enzymes, drug transporters, drug targets and other biomarker genes, possibly influencing clinical response, have been identified [15]. Present article will update the major findings related to the pharmacogenetics of genes affecting the response to ADs.

\section{ANTIDEPRESSANT DRUGS (ADS)}

All commercially available ADs target the monoaminergic system by either selectively or non-selectively blocking one of the three monoamine transporters (serotonin, noradrenaline and/or dopamine), by interfering with monoamine metabolism or by altering the pre- or postsynaptic transmission of the main receptors in these systems [16]. They can be divided into first- and second generation drugs. First-generation antidepressants (FGAs) include monoamine oxidase inhibitors (MAOI) and tricyclic antidepressants (TCA), which became available for therapy in the 1960s. MAOI increase monoamine levels by preventing their breakdown through blockage of the MAO. TCA mainly target both serotonergic and noradrenergic systems, by blocking the serotonin and noradrenaline transporters, therefore, interfering with pre- and post-synaptic monoamine transmission $[17,18]$. Secondgeneration antidepressants (SGAs) include several different classes of drugs with more selective profile and fewer side effects brought on the market in the early 1980s. These include the selective serotonin reuptake inhibitors (SSRI), serotonin-noradrenaline re-uptake inhibitors (SNRI), noradrenaline-dopamine reuptake inhibitors (NDRI) and noradrenaline reuptake inhibitors (NRI) which block more or less specifically the respective re-uptake transporter molecules. Noradrenergic and specific serotonergic antidepressants (NASSA), with mirtazapine as the only representative, block the presynaptic alpha 2 noradrenergic receptors as well as several serotonergic receptors. Moreover, there is a class of third-generation drugs (TGAs), characterized by compounds with non-monoaminergic mechanisms. Most of these compounds are based on peptidergic, glutamatergic or circadian rhythm related mechanisms, but a few still relate to a monoaminergic mechanism [19].

\section{PHARMACOKINETICS}

\section{Cytochrome P450}

The cytochrome P450 (CYP) system is a group of isoenzymes located primarily in the endoplasmic reticulum of hepatic cells. They catalyze oxidative or reductive reactions of endogenous lipophilic (steroids, bile acids, fatty acids, prostaglandins) and exogenous compounds (drugs) into more polar (hydrophilic) products, allowing their elimination in the urine. The human genome comprises $57 \mathrm{CYP}$ genes which are classified according to sequence homology into 18 families and 44 subfamilies. The CYP 1 to 3 families are involved in phase I drug metabolism, whereas CYP 4 to 51 are associated with 
endobiotic metabolism [20]. The metabolic activity of CYPs is genetically determined and mutations or polymorphisms in genes coding for CYP isoforms can result in enzyme variants with higher, lower or no activity. As shown in Table 1, the isoenzymes CYP1A2, CYP2C9/19, CYP2D6, and CYP3A4 are the major enzymes that catalyze antidepressant metabolic reactions [21]. In particular, most ADs are metabolized by polymorphic CYP2D6 and CYP2C19, and the differences in pharmacokinetic parameters like clearance or half-lives between the specific genotypes are extensively large [22, 23].

The CYP2D6 gene is highly polymorphic. More than 100 known allelic variants and subvariants have been identified, and there are substantial ethnic differences in the observed allele frequencies (Cytochrome P450 Nomenclature Committee at http://www.cypalleles.ki.se) [24]; however, many alleles are not typically tested for it in the clinical trials. The most commonly reported alleles are categorized into functional groups as follows: functional (e.g., $C Y P 2 D 6^{\star} 1$ and ${ }^{\star} 2$ ), reduced function (e.g., $C Y P 2 D 6^{*} 9,{ }^{\star} 10$, and ${ }^{*} 41$ ), and nonfunctional (e.g., CYP2D $6^{\star} 3$ $\left.{ }^{*} 6\right)[24,25]$. As CYP2D6 is subject to deletions or duplications, most clinical laboratories also report copy number. Deletions are indicated by the $C Y P 2 D 6^{*} 5$ allele, and gene duplications are denoted by an " $x N$ " following the allele (e.g., CYP2D $6^{\star} 1 x N$, where $x N$ represents the number of CYPD6 gene copies) [10, 24]. According to the number of gene copies or alleles inherited, individuals are classified as poor (PM), intermediate (IM), extensive (EM), or ultrarapid metabolizers (UM). Several studies have investigated the influence of CYP2D6 variants on clinical outcomes in patients treated with ADs [15]. Indeed, while some investigations reported positive association with therapeutic effects or side effects [26], other found lack of association [27]. Interestingly, the Pharmacogenetics Working Group of the Royal Dutch Pharmacists Association established dose recommendations for several TCA, SSRI and SNRI on the basis of CYP2D6 genotype [28]. Unfortunately, the heterogeneity of studied populations caused controversy about the association between CYP2D6 genotype and therapeutic effects or side effects [15].

Similar to CYP2D6, the CYP2C19 gene is highly polymorphic; at least 35 allelic variants and subvariants $\left({ }^{*} 1 \mathrm{~B}\right.$ to $\left.{ }^{\star} 28\right)$ have been identified [29]. Although there are ethnic differences in allele frequencies, the majority of patients carry a CYP $2 C 19^{\star} 1,{ }^{\star} 2$, or ${ }^{\star} 17$ allele [29]. CYP2C19* 1 is the wild-type allele encoding a fully functional enzyme, and CYP2C19* 2 is the most common loss-of-function allele. The CYP2C19* 17 allele results in the enhanced gene transcription probably with an increase of its metabolic activity. Pharmacogenetic studies investigating the influence of CYP2C19 variants on antidepressant outcome actually did

Table 1. CYP isoforms responsible for the biotransformation of antidepressants. Based on Spina et al., 2008 [21]

\begin{tabular}{ll} 
Antidepressant & Enzymes responsible for biotransformation \\
\hline Tricyclic antidepressants (demethylation) & CYP2C19, CYP1A2, CYP3A4 \\
\hline Tricyclic antidepressants (hydroxylation) & CYP2D6 \\
Fluoxetine & CYP2D6, CYP2C9, CYP2C19, CYP3A4 \\
\hline Paroxetine & CYP2D6, CYP3A4 \\
Fluvoxamine & CYP1A2, CYP2D6 \\
\hline Sertraline & CYP2C9, CYP2C19, CYP2D6, CYP3A4 \\
Citalopram & CYP2C19, CYP2D6, CYP3A4 \\
Escitalopram & CYP2C19, CYP2D6, CYP3A4 \\
Venlafaxine & CYP2D6, CYP3A4 \\
Duloxetine & CYP2D6, CYP1A2 \\
Milnacipran & CYP3A4 \\
Mirtazapine & CYP2D6, CYP1A2, CYP3A4 \\
Reboxetine & CYP3A4 \\
Trazodone & CYP3A4 \\
Nefazodone & CYP3A4 \\
Bupropion & CYP2B6 \\
Agomelatine & CYP1A2 \\
Vilazodone & CYP3A4, CYP2C19, CYP2D6 \\
\hline
\end{tabular}


not reach univocal results. While some studies indicated that $\mathrm{CYP} 2 \mathrm{C} 19^{*} 17$ increased the probability of therapeutic failure for antidepressants due to altered drug plasma concentrations, other did not confirm this finding [30-35]. Interestingly, de Vos et al. [31] investigated the relationship between CYP2C19 genotypes and metabolic parameters, including serum levels corrected for dose and metabolic ratio (MR), and found a significant association between CYP2C19* 17 allele and decreased MR for citalopram and amitriptyline. Moreover, homozygous CYP2C19^ 17 genotype was associated with lower serum concentration of escitalopram, which might imply increased risk of therapeutic failure [32].

\section{P-glycoprotein}

Polymorphisms in the drug transporter gene $\mathrm{ABCB} 1$, coding for P-glycoprotein (P-gp), a member of the ATP-binding cassette superfamily of membrane transport, account for differences in the clinically efficacy of many ADs, most likely by influencing their access to the brain [36]. The polymorphisms within $A B C B 1$ could influence intracerebral drug concentrations and, thereby, clinical response of patients treated with ADs which are substrates of P-gp like paroxetine, venlafaxine, fluoxetine and citalopram [36]. Several studies have investigated the possible association between $\mathrm{ABCB} 1$ variants, including the three most important SNPs rs1045642, rs2032582, and rs2032583, and antidepressant response and/or frequency of ADR [37-42]. However, the results of these investigations are somewhat controversial. Roberts et al. [37] showed no association between clinical response to nortriptyline (or fluoxetine) and rs1045642. A significant positive association was reported between the rs2032582 and response to paroxetine treatment [39]. Furthermore, $A B C B 1$ gene polymorphisms were associated with the clinical response to paroxetine in patients with MDD [39]. On the other hand, a subsequent study failed to replicate these findings [43]. Furthermore, the associations observed between $A B C B 1$ SNPs and paroxetine treatment response were not noted with other antidepressants [40]. Uhr et al. [44] used a tagging approach to investigate the influence of $A B C B 1$ SNPs in patients treated with various ADs (venlafaxine, citalopram, paroxetine, amitriptyline and mirtazapine). They evaluated the possibility of a link between remission rates in antidepressant-treated patients and all the $A B C B 1$ gene variants identified. No association was found between treatment response and the rs 1045642 or rs2032582 polymorphisms [44]. This finding in relation to the rs1045642 or rs 2032582 was subsequently replicated for citalopram, following the analysis of data from the large Sequenced Treatment Alternatives to Relieve Depression $\left(\mathrm{STAR}^{\star} \mathrm{D}\right)$ sample of depressed patients [37]. Furthermore, negative findings were also reported for rs10280101, rs7787082, rs2032583, rs2235040 in patients treated with duloxetine [45] and for rs2032582 in patients receiving amitriptyline [46]

\section{PHARMACODYNAMICS}

\section{Monoamine metabolic enzymes}

\section{Tryptophan hydroxylase (TPH)}

Tryptophan hydroxylase (TPH) catalyzes the first, rate-limiting step in serotonin (5-HT) synthesis, the hydroxylation of the essential amino-acid tryptophan to 5-hydroxytryptophan, which is further decarboxylated to 5 -HT by the aromatic l-amino-acid decarboxylase. There are two different $\mathrm{TPH}$ genes that encode two different homologous enzymes TPH1 and TPH2. TPH1 is mostly expressed in the skin, gut and pineal gland but it is also expressed in the central nervous system, while TPH2 is exclusively expressed in neuronal cell types and is the predominant isoform in the central nervous system $[47,48]$. Several studies suggested a role of $\mathrm{TPH} 1$ and TPH2 polymorphisms and response to ADs. In particular, rs1800532 polymorphism within TPH1 showed an association with both antidepressant clinical response and side effect profile $[49,50,51]$. Other polymorphisms such as rs1843809, rs1386494, rs1487276, rs10897346, rs1487278 and rs2171363 within TPH2 showed an association with antidepressant response [52, 53, 54]. These data suggest a role of these genes in the clinical outcome to antidepressant treatment.

\section{Catechol-O-methyl transferase (COMT)}

Catechol-O-methyltransferase (COMT) is one of several enzymes involved in the metabolism of catecholamines (dopamine, adrenaline and noradrenaline) [55]. Among several polymorphisms, the COMT functional polymorphism 
$\operatorname{val}(158)$ met (rs4680) is one of most intensively studied variants in psychiatric genetics. This polymorphism is associated with three-to-fourfold variation in COMT enzyme activity and it is also associated with an individual variation in COMT thermal instability [56]. Several studies investigated and showed an association between rs4680 and response to treatment with paroxetine, fluoxetine or mirtazapine [57-61]. However, other studies failed to replicate such an association $[62,63]$. Other COMT SNPs were studied for association with antidepressant treatment. In a clinical trial in patients with MDD, Perlis et al. [64] found an association between rs165599GG, rs174696CC and rs165774GG genotypes and response to duloxetine treatment. Furthermore, Kocabas et al. [65] carried out a study to define the functional impact of COMT genotypes/haplotypes on susceptibility and treatment response phenotypes of MDD. None of the seven SNPs under investigation (rs2075507, rs737865, rs6269, rs4633, rs4818, rs4680, and rs 165599) was significantly associated with MDD after permutation correction in single SNP analyses [65]. However, the combinations of G-T-G-G haplotype for rs6269, rs 4633 , rs4818 and rs4680 were only present in the MDD group and some haplotypes predicted response to treatment as well [65]. Although no replication studies have been performed so far, this result supports the role of COMT gene variants in the antidepressant response.

\section{Monoamine Oxidase A (MAO-A)}

There are two types of monoamine oxidases (MAO) in humans: MAO-A and MAO-B, and both are found in the central nervous system, in particular in neurons and astroglia. MAO-A is a major degrading enzyme in the metabolic pathways of monoamine neurotransmitters (dopamine, noradrenaline and serotonin). For this reason, polymorphisms within the MAO-A gene may influence treatment outcomes in patients with MDD. In particular, polymorphism in the promoter region of the MAOA gene, consisting of the repetitive sequence (VNTR), has been linked to variations in biological activity and, consequentially, in serotonin concentrations [66]. However, the results of studies examining the influence of this polymorphism on antidepressant response are inconsistent [67-71]. Others polymorphisms within this gene were more marginally studied, with some positive, but not replicated results. In particular, Peters et al. [52] found an association between rs1465108 and rs6323 and fluoxetine response, while Tadic et al. [67] reported an association between rs 1799835 and mirtazapine response, but only in female patients. Finally, the MAOA gene may be involved in placebo response [72].

\section{Serotonergic system}

\section{Serotonin transporter (SLC6A4)}

The serotonin transporter (SERT) gene, $S L C 6 A 4$, encodes the protein responsible for the reuptake of serotonin from the synapse after its release from the serotonergic neurons. It is a target of primary interest in the pharmacogenetics of antidepressants because it is the principal site of action of many ADs (mainly SSRI, SNRI, TCA). The SLC6A4 gene is located on chromosome 17 (17q11.1-q12) and has two well-studied polymorphisms [73]. The most investigated variant of this gene is located in the promoter region (5-HTTLPR) and it is able to impact the expression of SERT. It is a $44 \mathrm{bp}$ insertion/ deletion involving two units in a sequence of sixteen repeated elements: the long (l) allele has twice the expression in the basal state than the short (s) form. This polymorphism has been associated with several psychiatric disorders (i.e. bipolar disorder, anxiety disorders, eating disorders, substance abuse) and to pathological behaviors and personality traits related to anxiety, impulsivity and stress [73]. Concerning the antidepressant pharmacogenetics, the increasing evidence suggest that in Caucasian 1 allele is generally associated with better response to ADs, although negative findings were reported as well [73]. A recent meta-analysis showed that in Caucasians 5-HTTLPR may be a predictor of antidepressant response and remission, while in Asians it does not appear to play a major role [74]. Moreover, Murphy et al. [75] showed an interaction between the HTLPR genotype and the antidepressant used in the side effect profile suggesting that the effect of this polymorphism on outcome may depend on the mechanism of antidepressant action. Finally, other investigations suggested possible interactions between 5-HTTLPR genotype and drug plasma concentration, augmentation strategies, life events and gender [76-79]. Another polymorphism influencing SERT expression, described as $17 \mathrm{bp}$ VNTR polymorphism, was identified within intron 2 (STin2) [80]. Several studies reported an influence of STin2 on response to ADs, but 
other investigations were not able to repeat these findings [81-85]. Moreover, it was proposed that STin2 10/12 genotype may be associated with poorer antidepressant effect, especially in Asian populations [86]. While a pilot study suggested that Stin2 10/12 allele was associated with the occurrence of ADRs during the treatment with SSRI [87], a subsequent investigation did not confirm this finding [88]. More recently, rs25531, a single nucleotide polymorphism located just upstream of the 5HTTLPR, has been found to impact the response to ADs and shown to modulate the effect of the other 5HTTLPR alleles $[89,90]$. Nevertheless, the results are still controversial with both negative $[91,92,93]$. and positive findings [94].

\section{Serotonin receptors}

Activation of one or more serotonin receptors may play a role in mediating the antidepressant effects [95].

The 5-HT1A receptors are present preand postsynaptically in different brain regions that receive serotonergic input from the raphe nuclei: the frontal cortex, septum, amygdala, hippocampus and hypothalamus [96]. Converging lines of evidence from the animal studies suggest that agonists of 5-HT1A receptors produce antidepressant-like effects [96]. Moreover, its desensitization is thought to be one possible antidepressant mechanism [97]. The 5-HT1A receptor is coded by the HTR1A gene that contains about 50 known SNPs. The most investigated HTR1A polymorphisms are: rs6295, rs1800042, rs1799921, rs1800044 and rs1799920. The majority of results suggests an effect of the rs6295, functional variant in the promoter region, on treatment outcome with several classes of ADs, but negative results were also reported [97, 98, 99].

The 5HT2A receptor is a post-synaptic G-protein coupled receptor coded by the HTR2A gene. The 5HT2A receptors have been reported to mediate some of antidepressant effects seen in the experimental animal models of depression. Three important common variants of the 5HTR2A gene, rs6311, rs6313 and rs6314, have been in+-+-vestigated as functional candidates in several psychiatric disorders [15, 100]. These SNPs which are within the coding region of the gene have also been implicated in antidepressant response, although with contradictory results $[15,100]$.

The 5HT3 receptors are expressed throughout the central and peripheral nervous system and mediate a variety of physiological functions. Five different subunits, A-E, of 5-HT3 genes have been identified. Association studies have been carried out to establish the causal relationships between genetic variants within genes encoding 5HT3A and 5HT3B and side effects profile rather than clinical response [15]. These investigations focused only on SSRI and were performed on Japanese patients exclusively [15].

The 5HT6 receptor is a G protein-coupled receptor which is expressed almost exclusively in the brain. These receptors have been suggested to play a role in cognitive processes and in mood control, as well as in depression and anxiety [101]. Recently, the C267T variant (rs1805054), in the first exon of the gene, has been investigated for association with response to ADs in several studies. Despite preliminary negative results [102], a subsequent study reported that $\mathrm{C} / \mathrm{T}$ carriers showed better $\mathrm{AD}$ response [103]. Nevertheless, this finding was not replicated by further studies $[82,104]$.

\section{Noradrenergic system}

\section{Noradrenaline transporter (SLC6A2)}

Noradrenaline transporter (NET), encoded by SLC6A2, mediates reuptake of the released noradrenaline, thus playing a role in the limitation of signaling strength in the central and peripheral nervous systems. NET is also a target for TCA, NET-selective reuptake inhibitors and psychostimulants, including cocaine, methylphenidate and amphetamine $[105,106]$. Moreover, NET mutations have been implicated in depression or in some other psychiatric disorders [107, 108]. Several polymorphisms have been identified in the human NET gene such as rs5566, rs5563, rs5558, rs5569, rs36024 and rs2242446 variants which were proved to be functional and impact the effect of ADs [109, 110]. In particular, rs2242466 and rs5569 have been associated with antidepressant response to milnacipran [109] or nortriptyline 110]. Rrs36024, an intronic SNP in the SLC6A2 was associated with response to treatment with olanzapine-fluoxetine combination in patients with TRD [111]. Interestingly, stressors in early life may interact with polymorphisms in SLC6A2 to influence the response to antidepressant treatment [112]. In particular, the interaction between exposure to childhood trauma and the AA genotype of rs5569 in SLC6A2 was found 
to be associated with reduced response to ADs. This finding suggested that early life stress, like childhood maltreatment, could interact with genetic variants resulting in significantly poorer antidepressant response [112, 113, 114]. However, results are not unequivocal, and replication studies are warranted.

\section{Adrenoreceptors}

Among different adrenergic receptor subtypes, $\beta 1$ and $\alpha 2 \mathrm{~A}$ receptors (ADRB1 and ADRA2A) seem to play a role in response to antidepressant treatment. The $\beta 1$-adrenergic receptor is the most abundant subtype in the mammalian brain and known to regulate potently the synaptic plasticity activating the cAMP signaling cascade, as well as non-cAMP pathways such as ion channels. A functional polymorphism in this gene (Gly389Arg) was found to be implicated in the therapeutic response in patients with MDD, causing better and even faster response to treatment with TCA and SNRI [115]. However, another study failed to confirm the relevance of this gene in modulating the response to citalopram treatment [116]. With regard to ADRA2A gene, Perroud et al. [117] showed an association between rs11195419 polymorphism and nortriptyline treatment-associated suicidal ideation in the GENDEP study.

\section{Dopaminergic system}

\section{Dopamine transporter (SLC6A3)}

The dopamine transporter (DAT) acts to terminate dopaminergic neurotransmission through reuptake of dopamine from the synaptic cleft into presynaptic neurons. DAT is thought to be implicated in several dopamine-related disorders and, being the target for therapeutic and illicit psycho-stimulant drugs like antidepressants and cocaine, it has been studied intensively $[118,119,120]$. There are at least 502 known variants of this gene. A VNTR polymorphism in the 3'UTR of gene SLC6A3 encoding the high-affinity dopamine transporter DAT1 was shown to be associated with various psychiatric phenotypes [121], including bipolar affective disorders [122, 123]. Levels of SLC6A3 expression were higher in carriers of the 10-repeat allele than in carriers of the 9-repeat allele [124]. Kirchheiner et al. [125] showed an association between the 9/10 and 9/9 genotypes and higher risk of poorer and slower response to various ADs than the 10/10 genotype. Moreover, the 10/10 genotype was found to respond preferentially to methylphenidate added to SSRI [126].

\section{Dopamine receptors}

Dopaminergic receptors are divided into D1-like family (D1 and D5) and D2-like family (D2, D3, D4) based on their localization in dopaminergic synapses (presynaptic and pre/postsynaptic, respectively) and on their link to different $G$ proteins (Gs and Gi, respectively) [127]. D2-like family was associated with depressive disorder and some evidence suggested an implication of D2 receptors in treatment response [128]. Perlis et al. [129] showed an association between the genetic variants rs167770, rs6280 and rs2134655 within D3 and the olanzapine/fluoxetine combination in patients with bipolar depression. Serretti et al. [130] investigated VNTR polymorphism in exon 3 of D4 receptor gene, in relationship with antidepressant response, unfortunately with negative results.

\section{Glutamatergic system}

According to monoaminergic theory, depression is caused by underactivity of brain monoamines (serotonin, dopamine and noradrenaline) and can be improved by medications which correct such imbalance. In recent years, the glutamatergic theory of depression has gained growing interest, as many studies have documented the important role played by the glutamatergic system in the pathophysiology of depression and mechanism of action of ADs [131, 132]. A number of pharmacogenetic studies have evaluated the effect of different glutamatergic polymorphisms on treatment outcome in MDD. In particular, GRIK4 (glutamate receptor, ionotropic, kainate 4) has been repeatedly investigated with controversial results $[133,134,135]$. Recently, Fabbri et al. [136] have investigated 44 glutamatergic genes in 1541 patients with MDD from the STAR ${ }^{\star} \mathrm{D}$ genome wide dataset. The rs1083801 within the GRM7 (glutamate receptor, metabotropic 7) gene was identified as putative predictor of an early antidepressant response (2nd week) compared to later (from the week 4 to 14), or non-response.

\section{Signal Transduction and Transcription Factors}

Guanine nucleotide binding protein (G protein), beta polypeptide 3 (coded by the GNB3 gene) 
is present in all cells of the body and it has a key role in the downstream signalling cascade following the monoamine receptor activation [137]. The C825T (rs5443) polymorphism in the GNB3 gene has been associated with antidepressant treatment response [138]. Keers et al. [139] reported the analysis of data from GENDEP in which the TT genotype of rs5443 was significantly associated with a superior response to nortriptyline. In addition, the same genotype predicted fewer incidents of treatment-emergent insomnia and greater weight gain in the same drug. While one study found that the $\mathrm{T}$ allele predicted better antidepressant response [140], another investigation reported an opposite association [141]. On the other hand, Kang et al. [142] found no evidence that this polymorphism was related to therapeutic response in Korean MDD patients treated with mirtazapine.

Glycogen synthase kinase 3 alpha (GSK3-A) is involved in the control of gene expression, cell behavior, cell adhesion and cell polarity, and plays a major role in neurodevelopment, regulation of neuroplasticity and cell survival [143]. Glycogen synthase kinase beta (GSK3-b) is implicated in signaling cascades in response to serotonin, 5HT1 receptor agonists, lithium and antidepressants [144]. Particularly, GSK3A may be an important mediator of serotonin action in the brain and, consequently, of depressive-like behaviors [145]. A promoter single nucleotide polymorphism (rs334558) within GSK3A is associated with transcriptional strength and the $\mathrm{T}$ allele has greater activity [146]. This polymorphism is likely to be associated with antidepressant response, as suggested by a study in bipolar depressed patients treated with total sleep deprivation where the TT homozygote showed better response [147]. In contrast to these results, other investigations reported that the $\mathrm{C}$ allele resulted in favorable variant [148, 149].

cAMP responsive element binding protein 1 (CREB1) is a member of the leucine zipper family of DNA binding proteins and is under the inhibitory control of several kinases including GSK3A [143]. An increasing number of studies has been recently focused on the role of CREB1 in antidepressant response mechanism. A preliminary investigation suggested that some alleles or haplotypes of CREB1 gene could be related to TRD, but not to response to antidepressant treatment [150]. A recent case-control study of 14 genetic variants within the CREB,
CREB binding protein (CREBBP) and cAMP response element-modulator (CREM) found no association between these genes and diagnosis and treatment response in patients with MDD and bipolar disorder [151]. In conclusion, referring to signal transduction and transcription factors, the above genes have been only marginally investigated and a number of promising genes for their biological function have been proposed (e.g., CAMK2 subtypes, MAPK3 and 1 , PRKAR subtypes), but not yet investigated [132].

\section{Hypothalamic-pituitary-adrenal (HPA) axis and stress hormone system}

\section{CRH receptors (CRHR1 and CRHR2)}

Corticotropin releasing hormone $(\mathrm{CRH})$ receptors 1 and 2 (CRHR1 and CRHR2) are mediators of the effect of glucocorticoids in the central nervous system and, interestingly, CRHR1 antagonists have demonstrated antidepressant effect both in animals and humans [152-155]. The CRHR1 rs242941 G/G genotype and one haplotype block including two other SNPs, rs 1876828 and rs242939, were associated with response to fluoxetine $[156,157]$. These results were not confirmed by the following studies $[158,159]$. On the other hand, rs4792888 showed marginal evidence of association with desipramine response [160]. Other investigations showed a possible involvement of rs2270007 [158] and rs2267716-rs255105 [159] within CRHR2 in citalopram response, and of rs917195 in desipramine efficacy [161].

\section{Glucocorticoid receptor (GR)}

The glucocorticoid receptor (GR, coded by the $\mathrm{NR} 3 \mathrm{C} 1$ gene) has been investigated in pharmacogenetic studies. Several polymorphisms within this gene have been described and associated with MDD and antidepressant treatment. In particular, the BclI and ER22/23EK (rs6189 and rs6190) polymorphisms were associated with susceptibility to develop MDD $[162,163]$. In addition, both polymorphisms may affect clinical response to antidepressant treatment [163]. Moreover, the rs852977, rs10482633, rs10052957 polymorphisms were associated with the nortriptyline and escitalopram response in the GENDEP study [164]. Notwithstanding, the GENDEP study has not corroborated the role of rs6190 in response to antidepressant treatment [164]. 


\section{Brain-Derived Neurotrophic Factor (BDNF)}

There are several lines of evidence suggesting that Brain-Derived Neurotrophic Factor (BDNF) is involved in both pathogenesis and treatment of depression. An increase in BDNF expression has been recently confirmed in the peripheral cells of depressed patients during the treatment with escitalopram or nortriptyline [165]. Indeed, several treatment modalities (e.g. antidepressant therapy, electroconvulsive therapy, transcranial magnetic stimulation) of depression upregulate the expression of cerebral BDNF [166-169]. Quite a few evidence support an influence of BDNF polymorphisms in antidepressant response. In this respect, the most investigated variant within the BDNF gene is rs6265 (196G/A or Val66Met) [170]. Pharmacogenetic studies mainly suggested a positive molecular heterosis effect [171, 172, 173], together with a more favorable outcome in Met allele carriers [174-177]. On the other hand, Chi et al. [178] and Domschke et al. [179] showed better response in the rs6265 $\mathrm{Val} /$ Val genotype. Moreover, several negative findings were also found $[180,181]$ in the large GENDEP sample [164]. A similar heterosis effect was also reported for another SNP within BDNF (rs90887) [182]. Preliminary findings were provided for other BDNF SNPs (rs90887, rs61888800, rs7124442 and rs11030104) [179, $182,183]$. A strong association was established between rs962369 and an increase in suicidal ideation during antidepressant treatment [117]. Interestingly, some SNPs of the BDNF receptor gene NTRK2 were also associated with AD response [184] In addition, some variants within NTRK2 and also interactions between variants of BDNF and NTRK2 genes might have effect on antidepressant treatment-associated suicidality $[117,185,186]$.

\section{Other gene variants}

Besides those described, there are many genes that may influence both the onset and evolution of MDD and the effects of antidepressant treatment. The vascular endothelial growth factor (VEGF) has been implicated in neuroprotection and neurogenesis [187]. Dysbindin gene (dystrobrevin-binding-protein 1, DTNBP1) variants have been associated with several psychiatric conditions including mood disorders and antidepressant efficacy. Pharmacogenetic studies reported both negative and positive findings concerning the possible association between variants of DTNBP1 gene (rs3213207, rs2005976, rs760761 and rs2619522) and clinical response to SSRI [188-191]. The angiotensin converting enzyme (ACE) acts in the central nervous system to degrade several neuropeptides including substance P. Substance P receptor (NK1) antagonists have been suggested to have possible antidepressant effects. The presence of a deletion variant $(\mathrm{D} /)$ in the $A C E$ gene was found to be associated with higher ACE plasma levels, higher substance P levels and faster response to antidepressant treatment $[192,193]$. Concerning the Circadian Locomotor Output Cycles Kaput (CLOCK) gene, one study demonstrated significant association between rs3736544 and response/remission to fluvoxamine treatment in a Japanese population $[194,195]$.

\section{Genome Wide Association Studies (GWAS)}

Very recent data have shown that genomewide association studies (GWAS) and, in particular, copy number variations (CNVs) have created a revolution in our knowledge about many disorders and response to treatment. GWAS is an approach that involves rapidly scanning markers across the complete sets of DNA, or genomes, of many people to find genetic variations associated with particular disease. Recently, GWAS have been proposed as most promising technique to overcome the major limitations of candidate gene studies. One of the limits of this methodology is the risk of false positive results [196]. The number of GWAS performed on pharmacogenetics of ADs is limited and the results need replication. Recently, GWAS have been performed within the GENDEP project and the STAR ${ }^{\star} \mathrm{D}[7,186$, 197-200]. One of the major limits of GWAS is their incapacity to detect rare genetic variants $(<1 \%$ of the population). Indeed, current GWAS technologies are able to detect only association of genetic variants present in $5 \%$ or more of the population [197]. So far, the results obtained by GWAS have been disappointing, and, therefore, large meta-analysis to achieve genome-wide significance are needed [201]. Recently, pathway analysis has been proposed in order to balance the limitations of GWAS hypothesis free approach. The basic principle of the method is 
Table 2. Summary of the pharmacogenetic association studies focused on antidepressant pharmacological treatment

\begin{tabular}{|c|c|c|c|}
\hline Genes & Polymorphisms & Drug & Reference \\
\hline \multirow{3}{*}{$\mathrm{ABCB} 1$} & Rs2032582 & \multirow{3}{*}{ Paroxetine } & {$[39 ; 37-42]$} \\
\hline & Rs2032583 & & \multirow{2}{*}{ [37-42] } \\
\hline & Rs1045642 & & \\
\hline TPH1 & Rs1800532 & ADs & [49-51] \\
\hline \multirow{6}{*}{$\mathrm{TPH} 2$} & Rs1843809 & \multirow{6}{*}{ - ADs } & \multirow{6}{*}[52-54]{} \\
\hline & Rs1386494 & & \\
\hline & Rs1487276 & & \\
\hline & Rs10897346 & & \\
\hline & Rs1487278 & & \\
\hline & Rs2171363 & & \\
\hline \multirow{9}{*}{ COMT } & Rs4680 & $\begin{array}{l}\text { ADs (in particular Paroxetine; } \\
\text { Fluoxetine; Mirtazapine) }\end{array}$ & {$[57-63 ; 65]$} \\
\hline & Rs165599 & ADs (in particular Duloxetine) & {$[64 ; 65]$} \\
\hline & Rs174696 & \multirow{2}{*}{ - Duloxetine } & \multirow{2}{*}{ [64] } \\
\hline & Rs165774 & & \\
\hline & Rs2075507 & \multirow{5}{*}{ ADs } & \multirow{5}{*}[65]{} \\
\hline & Rs737865 & & \\
\hline & Rs6269 & & \\
\hline & Rs4633 & & \\
\hline & Rs4818 & & \\
\hline \multirow{4}{*}{ MAO-A } & promoter VNTR & ADs & {$[67-71]$} \\
\hline & Rs1465108 & Fluoxetine & \multirow{3}{*}[52;67]{} \\
\hline & Rs6323 & Fluoxetine & \\
\hline & Rs1799835 & Mirtazapine & \\
\hline \multirow{3}{*}{ SLC6A4 } & 5-HTTLPR ins & ADs & [73] \\
\hline & STin 2 & ADs; SSRI & [81-88] \\
\hline & Rs25531 & ADs & [89-94] \\
\hline \multirow{5}{*}{ HTR1A } & Rs6295 & \multirow{5}{*}{ ADs } & \multirow{5}{*}{ [97-99] } \\
\hline & Rs1800042 & & \\
\hline & Rs1799921 & & \\
\hline & Rs1800044 & & \\
\hline & Rs1799920 & & \\
\hline \multirow{3}{*}{ HTR2A } & Rs6311 & \multirow{3}{*}{ ADs } & \multirow{3}{*}[15;100]{} \\
\hline & Rs6313 & & \\
\hline & Rs6314 & & \\
\hline HTR6 & Rs1805054 & ADs & {$[82 ; 103 ; 104]$} \\
\hline \multirow{7}{*}{ SLC6A2 } & Rs5566 & \multirow{4}{*}{ - ADs } & \\
\hline & Rs5563 & & [100. 110 \\
\hline & Rs5558 & & {$[109 ; 110]$} \\
\hline & Rs36024 & & \\
\hline & Rs5569 & ADs (in particular milnacipran, & {$[109 ; 110 ;$} \\
\hline & Rs2242446 & nortriptyline) & $112-114]$ \\
\hline & Rs36024 & $\begin{array}{l}\text { Olanzapine- } \\
\text { Fluoxetine(combination) }\end{array}$ & {$[111]$} \\
\hline ADRB1 & Gly389Arg & Citalopram; TCA, SNRI & {$[115 ; 116]$} \\
\hline ADRA2A & Rs11195419 & Notriptyline & {$[117]$} \\
\hline $\mathrm{SIC} \triangle 2$ & 9/10 and 9/9 VNTR & ADs & {$[125]$} \\
\hline SLCOAS & 10/10 VNTR & Methylphenidate plus SSRI & [126] \\
\hline & Rs167770 & & \\
\hline D3 & Rs6280 & 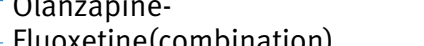 & [129] \\
\hline & Rs2134655 & & \\
\hline
\end{tabular}




\begin{tabular}{|c|c|c|c|}
\hline Genes & Polymorphisms & Drug & Reference \\
\hline D4 & VNTR in exon3 & ADs & {$[130]$} \\
\hline GRM7 & Rs1083801 & ADs & [136] \\
\hline GNB3 & Rs5443 & $\begin{array}{l}\text { ADs (in particular Notriptyline, } \\
\text { Mirtazapine) }\end{array}$ & {$[139-142]$} \\
\hline GSK3A & Rs334558 & ADs & [146-147] \\
\hline \multirow{3}{*}{ CRHR1 } & Rs242941 & \multirow{2}{*}{ Fluoxetine } & \multirow{2}{*}{ [156-159] } \\
\hline & Rs1876828-Rs242939 & & \\
\hline & Rs4792888 & Desipramine & [160] \\
\hline \multirow{3}{*}{ CRHR2 } & Rs2270007 & \multirow{2}{*}{ Citalopram } & {$[158]$} \\
\hline & Rs2267716-Rs255105 & & [159] \\
\hline & Rs917195 & Desipramine & [161] \\
\hline \multirow{5}{*}{ NR3C1 } & Rs6189 & \multirow{2}{*}{ ADs } & [163] \\
\hline & Rs6190 & & {$[163 ; 164]$} \\
\hline & Rs852977 & \multirow{3}{*}{ Nortriptyline; Escitalopram } & \multirow{3}{*}[164]{} \\
\hline & Rs10482633 & & \\
\hline & Rs10052957 & & \\
\hline \multirow{6}{*}{ BNDF } & Rs6265 & \multirow{6}{*}{ ADs } & $\begin{array}{l}{[164 ; 170 ;} \\
174-181]\end{array}$ \\
\hline & Rs90887 & & \multirow{4}{*}[179;182;183]{} \\
\hline & Rs61888800 & & \\
\hline & Rs7124442 & & \\
\hline & Rs11030104 & & \\
\hline & Rs962369 & & {$[117]$} \\
\hline \multirow{4}{*}{ DTNBP1 } & Rs3213207 & \multirow{4}{*}{ - SSRI } & \multirow{4}{*}[188-191]{} \\
\hline & Rs2005976 & & \\
\hline & Rs760761 & & \\
\hline & Rs2619522 & & \\
\hline CLOCK & Rs3736544 & Fluvoxamine & {$[194 ; 195]$} \\
\hline
\end{tabular}

the analysis of variants within genes involved in the same biological pathway [202, 203]. Other than pathway analysis, gene - gene interactions can be investigated through the study of epistatic effects, that is, the statistical finding of an interaction between polymorphisms in different genes [204, 205].

\section{CONCLUSIONS}

There is great hope that the field of pharmacogenomics will offer personalized medicine treatments based on genetic profiles. Pharmacogenetic studies of antidepressant response have suggested several strong candidate genes involved in the pharmacokinetics and pharmacodynamics of these agents (Table 2). However, comparisons across studies are complicated by a variety of critical methodological aspects such as differences in inclusion criteria, type of medication, outcome measure, evaluation of adverse effects, genetic coverage and ethnicity. Even when certain polymorphisms appear to show replicable association with the antidepressant treatment response, effect sizes across studies can be very different and it is difficult to discriminate whether the observed differences are chance findings or in fact related to clinical differences in the sample. Some genes also appear to interfere specifically with the response to selected treatments, while others modulate response to various antidepressant treatments, including non-pharmacological interventions. In summary, with more GWAS still outstanding, no clinically tested predictive markers have been yet established and larger, more refined studies on phenotypic and genetic level are needed.

\section{Conflict of Interest Statement}

The authors certify that there are no potential conflicts of interest. 


\section{REFERENCES}

1. Wells KB, Sherbourne CD. Functioning and utility for current health of patients with depression or chronic medical conditions in managed, primary care practices. Arch Gen Psychiatry. 1999; 56(10):897-904

2. Sprangers MA, de Regt EB, Andries F, van Agt HM, Bijl RV, de Boer JB, et al. Which chronic conditions are associated with better or poorer quality of life? J Clin Epidemiol. 2000; 53(9):895-907.

3. Wells KB, Stewart A, Hays RD, Burnam MA, Rogers $W$, Daniels $M$, et al. The functioning and well-being of depressed patients. Results from the Medical Outcomes Study. JAMA. 1989; 262(7):914-9.

4. Murray CJ, Lopez AD. Evidence-based health policy - lessons from the Global Burden of Disease Study. Science. 1996; 274(5288):740-3.

5. Laje G, McMahon FJ. The pharmacogenetics of major depression: past, present, and future. Biol Psychiatry. 2007; 62(11):1205-7.

6. Mulder RT, Joyce PR, Frampton CM, Luty SE, Sullivan PF. Six months of treatment for depression: outcome and predictors of the course of illness. Am J Psychiatry. 2006; 163(1):95-100.

7. Ising M, Lucae S, Binder EB, Bettecken T, Uhr M, Ripke $S$, et al. A genomewide association study points to multiple loci that predict antidepressant drug treatment outcome in depression. Arch Gen Psychiatry. 2009; 66(9):966-75.

8. Rush AJ, Trivedi MH, Wisniewski SR, Nierenberg AA, Stewart JW, Warden D, et al. Acute and longer-term outcomes in depressed outpatients requiring one or several treatment steps: a STAR ${ }^{\circ}$ report. Am J Psychiatry. 2006; 163(11):1905-17.

9. Trivedi MH, Fava M, Wisniewski SR, Thase ME, Quitkin F, Warden D, et al. Medication augmentation after the failure of SSRIs for depression. N Engl J Med. 2006; 354(12):1243-52.

10. Gartlehner G, Gaynes BN, Hansen RA, Thieda P, DeVeaugh-Geiss A, Krebs EE, et al. Comparative benefits and harms of second-generation antidepressants: background paper for the American College of Physicians. Ann Intern Med. 2008; 149(10):734-50.

11. O'Reilly RL, Bogue L, Singh SM. Pharmacogenetic response to antidepressants in a multicase family with affective disorder. Biol Psychiatry. 1994; 36(7):467-71.

12. Schosser A, Kasper S. The role of pharmacogenetics in the treatment of depression and anxiety disorders. Int Clin Psychopharmacol. 2009; 24(6):277-88.

13. Drago A, De Ronchi D, Serretti A. Pharmacogenetics of antidepressant response: an update. Hum Genomics. 2009; 3(3):257-74.

14. Horstmann S, Binder EB. Pharmacogenomics of antidepressant drugs. Pharmacol Ther. 2009; 124(1):57-73.

15. Crisafulli C, Fabbri C, Porcelli S, Drago A, Spina E, De Ronchi D, et al. Pharmacogenetics of antidepressants. Front Pharmacol. 2011; 2:6.

16. Nemeroff CB, Owens MJ. Treatment of mood disorders. Nat Neurosci. 2002; 5 Suppl:1068-70.

17. Blier P, de Montigny C. Current advances and trends in the treatment of depression. Trends Pharmacol Sci. 1994; 15(7):220-6.

18. Stahl SM. Basic psychopharmacology of antidepressants, part 1: Antidepressants have seven distinct mechanisms of action. J Clin Psychiatry. 1998; 59 Suppl 4:5-14.
19. Racagni G, Popoli M. Cellular and molecular mechanisms in the long-term action of antidepressants. Dialogues Clin Neurosci. 2008; 10(4):385-400.

20. Nelson DR. The cytochrome $\mathrm{p} 450$ homepage. Hum Genomics. 2009; 4(1):59-65.

21. Spina E, Santoro V, D’Arrigo C. Clinically relevant pharmacokinetic drug interactions with second-generation antidepressants: an update. Clin Ther. 2008; 30(7):1206-27.

22. Kirchheiner J, Seeringer A. Clinical implications of pharmacogenetics of cytochrome P450 drug metabolizing enzymes. Biochim Biophy Acta. 2007; 1770(3):489-94.

23. Seeringer A, Kirchheiner J. [CYP2D6-, CYP2C9and CYP2C19-based dose adjustments: when do they make sense?]. Internist (Berl). 2008; 49(7):877-83.

24. Crews KR, Gaedigk A, Dunnenberger HM, Klein TE, Shen DD, Callaghan JT, et al. Clinical Pharmacogenetics Implementation Consortium (CPIC) guidelines for codeine therapy in the context of cytochrome P450 2D6 (CYP2D6) genotype. Clin Pharmacol Ther. 2012; 91(2):321-6.

25. Gaedigk A, Simon SD, Pearce RE, Bradford LD, Kennedy MJ, Leeder JS. The CYP2D6 activity score: translating genotype information into a qualitative measure of phenotype. Clin Pharmacol Ther. 2008; 83(2):234-42.

26. Rau T, Wohlleben G, Wuttke H, Thuerauf N, Lunkenheimer J, Lanczik M, et al. CYP2D6 genotype: impact on adverse effects and nonresponse during treatment with antidepressants - a pilot study. Clin Pharmacol Ther. 2004; 75:386-93.

27. Serretti A, Calati R, Massat I, Linotte S, Kasper S, Lecrubier Y, et al. Cytochrome P450 CYP1A2, CYP2C9, CYP2C19 and CYP2D6 genes are not associated with response and remission in a sample of depressive patients. Int Clin Psychopharmacol. 2009; 24:250-6.

28. Swen JJ, Nijenhuis M, de Boer A, Grandia L, Maitland-van der Zee AH, Mulder $\mathrm{H}$, et al. Pharmacogenetics: from bench to byte--an update of guidelines. Clin Pharmacol Ther. 2011; 89(5):662-73.

29. Scott SA, Sangkuhl K, Gardner EE, Stein CM, Hulot JS, Johnson JA, et al. Clinical Pharmacogenetics Implementation Consortium guidelines for cytochrome P450-2C19 (CYP2C19) genotype and clopidogrel therapy. Clin Pharmacol Ther. 2013; 90(2): 328-32.

30. Sim SC, Risinger C, Dahl ML, Aklillu E, Christensen $\mathrm{M}$, Bertilsson L, et al. A common novel CYP2C19 gene variant causes ultrarapid drug metabolism relevant for the drug response to proton pump inhibitors and antidepressants. Clin Pharmacol Ther. 2006; 79(1): 103-13.

31. de Vos A, van der Weide J, Loovers HM. Association between CYP2C19*17 and metabolism of amitriptyline, citalopram and clomipramine in Dutch hospitalized patients. Pharmacogenomics J. 2011; 11(5): 359-67.

32. Rudberg I, Mohebi B, Hermann M, Refsum H, Molden E. Impact of the ultrarapid CYP2C19*17 allele on serum concentration of escitalopram in psychiatric patients. Clin Pharmacol Ther. 2008; 83(2):322-7.

33. Li-Wan-Po A, Girard T, Farndon P, Cooley C, Lithgow J. Pharmacogenetics of CYP2C19: functional and clinical implications of a new variant CYP2C19*17. Br J Clin Pharmacol. 2010; 69(3):222-30. 
34. Ohlsson Rosenborg S, Mwinyi J, Andersson M, Baldwin RM, Pedersen RS, Sim SC, et al. Kinetics of omeprazole and escitalopram in relation to the CYP2C19*17 allele in healthy subjects. Eur J Clin Pharmacol. 2008; 64(12):1175-9.

35. Schenk PW, van Vliet M, Mathot RA, van Gelder T, Vulto AG, van Fessem MA, et al. The CYP2C19*17 genotype is associated with lower imipramine plasma concentrations in a large group of depressed patients. Pharmacogenomics J. 2010; 10(3):219-25.

36. Rosenhagen MC, Uhr M. The clinical impact of $A B C B 1$ polymorphisms on the treatment of psychiatric diseases. Curr Pharm Des. 2011; 17(26):2843-51.

37. Roberts RL, Joyce PR, Mulder RT, Begg EJ, Kennedy MA. A common P-glycoprotein polymorphism is associated with nortriptyline-induced postural hypotension in patients treated for major depression. Pharmacogenomics J. 2002; 2(3):191-6.

38. Gex-Fabry M, Eap CB, Oneda B, Gervasoni N, Aubry JM, Bondolfi G, et al. CYP2D6 and ABCB1 genetic variability: influence on paroxetine plasma level and therapeutic response. Ther Drug Monit. 2008; 30(4): 474-82.

39. Kato M, Fukuda T, Serretti A, Wakeno M, Okugawa $G$, Ikenaga Y, et al. ABCB1 (MDR1) gene polymorphisms are associated with the clinical response to paroxetine in patients with major depressive disorder. Prog Neuropsychopharmacol Biol Psychiatry. 2008; 32(2):398-404.

40. Nikisch G, Eap CB, Baumann P. Citalopram enantiomers in plasma and cerebrospinal fluid of $A B C B 1$ genotyped depressive patients and clinical response: a pilot study. Pharmacol Res. 2008; 58(5-6):344-7.

41. Jongen PJ, Zoll GJ, Beaumont M, Melchers WJ, van de Putte LB, Galama JM. Polymyositis and dermatomyositis: no persistence of enterovirus or encephalomyocarditis virus RNA in muscle. Ann Rheum Dis. 1993; 52(8):575-8.

42. Sarginson JE, Lazzeroni LC, Ryan HS, Ershoff BD, Schatzberg AF, Murphy GM Jr. ABCB1 (MDR1) polymorphisms and antidepressant response in geriatric depression. Pharmacogenet Genomics. 2010; 20(8):467-75.

43. Mihaljevic Peles A, Bozina N, Sagud M, Rojnic Kuzman M, Lovric M. MDR1 gene polymorphism: therapeutic response to paroxetine among patients with major depression. Prog Neuropsychopharmacol Biol Psychiatry. 2008; 32(6):1439-44

44. Uhr M, Tontsch A, Namendorf C, Ripke S, Lucae S, Ising $\mathrm{M}$, et al. Polymorphisms in the drug transporter gene ABCB1 predict antidepressant treatment response in depression. Neuron. 2008; 57(2):203-9.

45. Perlis RH, Fijal B, Dharia S, Heinloth AN, Houston JP. Failure to replicate genetic associations with antidepressant treatment response in duloxetine-treated patients. Biol Psychiatry. 2010; 67(11):1110-3.

46. Laika B, Leucht S, Steimer W. ABCB1 (P-glycoprotein/MDR1) gene G2677T/a sequence variation (polymorphism): lack of association with side effects and therapeutic response in depressed inpatients treated with amitriptyline. Clin Chem. 2006; 52(5):893-5.

47. Walther DJ, Peter JU, Bashammakh S, Hortnagl H, Voits M, Fink H, et al. Synthesis of serotonin by a second tryptophan hydroxylase isoform. Science. 2003; 299(5603):76.
48. Walther DJ, Bader M. A unique central tryptophan hydroxylase isoform. Biochem Pharmacol. 2003; 66(9):1673-80.

49. Anttila S, Kampman O, Illi A, Rontu R, Lehtimaki T, Leinonen E. Association between 5-HT2A, TPH1 and GNB3 genotypes and response to typical neuroleptics: a serotonergic approach. BMC Psychiatry. 2007; 7:22.

50. Viikki M, Kampman O, Illi A, Setälä-Soikkeli E, Anttila S, Huuhka M, et al. TPH1 218A/C polymorphism is associated with major depressive disorder and its treatment response. Neurosci Lett. 2010; 468(1):80-4.

51. Secher A, Bukh J, Bock C, Koefoed P, Rasmussen $\mathrm{HB}$, Werge T, et al. Antidepressive-drug-induced bodyweight gain is associated with polymorphisms in genes coding for COMT and TPH1. Int Clin Psychopharmacol. 2009; 24(4):199-203.

52. Peters EJ, Slager SL, McGrath PJ, Knowles JA, Hamilton SP. Investigation of serotonin-related genes in antidepressant response. Mol Psychiatry. 2004; 9(9): 879-89.

53. Tzvetkov MV, Brockmoller J, Roots I, Kirchheiner J. Common genetic variations in human brain-specific tryptophan hydroxylase- 2 and response to antidepressant treatment. Pharmacogenet Genomics. 2008; 18(6):495-506.

54. Tsai SJ, Hong CJ, Liou YJ, Yu YW, Chen TJ, Hou SJ, et al. Tryptophan hydroxylase 2 gene is associated with major depression and antidepressant treatment response. Prog Neuropsychopharmacol Biol Psychiatry. 2009; 33(4):637-41.

55. Karhunen T, Tilgmann C, Ulmanen I, Panula P. Catechol-0-methyltransferase (COMT) in rat brain: immunoelectron microscopic study with an antiserum against rat recombinant COMT protein. Neurosci Lett. 1995; 187(1):57-60.

56. Lachman HM, Morrow B, Shprintzen R, Veit S, Parsia SS, Faedda G, et al. Association of codon 108/158 catechol-0-methyltransferase gene polymorphism with the psychiatric manifestations of velo-cardio-facial syndrome. Am J Med Genet. 1996; 67(5):468-72.

57. Arias B, Serretti A, Lorenzi C, Gasto C, Catalan R, Fananas L. Analysis of COMT gene (Val 158 Met polymorphism) in the clinical response to SSRIs in depressive patients of European origin. J Affect Disord. 2006; 90(2-3):251-6.

58. Benedetti F, Colombo C, Pirovano A, Marino E, Smeraldi E. The catechol-O-methyltransferase Val(108/158)Met polymorphism affects antidepressant response to paroxetine in a naturalistic setting. Psychopharmacology (Berl). 2009; 203(1):155-60.

59. Leuchter AF, McCracken JT, Hunter AM, Cook IA, Alpert JE. Monoamine oxidase a and catechol-o-methyltransferase functional polymorphisms and the placebo response in major depressive disorder. J Clin Psychopharmacol. 2009; 29(4):372-7.

60. Szegedi A, Rujescu D, Tadic A, Muller MJ, Kohnen $\mathrm{R}$, Stassen $\mathrm{HH}$, et al. The catechol-O-methyltransferase Val108/158Met polymorphism affects short-term treatment response to mirtazapine, but not to paroxetine in major depression. Pharmacogenomics J. 2005; 5(1):49-53.

61. Tsai SJ, Gau YT, Hong CJ, Liou YJ, Yu YW, Chen TJ. Sexually dimorphic effect of catechol-O-methyltransferase val158met polymorphism on clinical response to fluoxetine in major depressive patients. J Affect Disord. 2009; 113(1-2):183-7.

62. Bukh JD, Bock C, Vinberg M, Werge T, Gether U, Kessing LV. No interactions between genetic 
polymorphisms and stressful life events on outcome of antidepressant treatment. Eur Neuropsychopharmacol. 2009; 20(5):327-35.

63. Illi A, Setälä-Soikkeli E, Kampman O, Viikki M, Nuolivirta T, Poutanen O, et al. Catechol-Omethyltransferase val108/158met genotype, major depressive disorder and response to selective serotonin reuptake inhibitors in major depressive disorder. Psychiatry Res. 2010; 176(1):85-7.

64. Perlis RH, Fijal B, Adams DH, Sutton VK, Trivedi $\mathrm{MH}$, Houston JP. Variation in catechol-O-methyltransferase is associated with duloxetine response in a clinical trial for major depressive disorder. Biol Psychiatry. 2009; 65(9):785-91.

65. Kocabas NA, Faghel C, Barreto M, Kasper S, Linotte S, Mendlewicz J, et al. The impact of catechol-0-methyltransferase SNPs and haplotypes on treatment response phenotypes in major depressive disorder: a case-control association study. Int Clin Psychopharmacol. 2010; 25(4):218-27.

66. Sabol SZ, Hu S, Hamer D. A functional polymorphism in the monoamine oxidase A gene promoter. Hum Genet. 1998; 103(3):273-9.

67. Tadic A, Muller MJ, Rujescu D, Kohnen R, Stassen $\mathrm{HH}$, Dahmen N, et al. The MAOA T941G polymorphism and short-term treatment response to mirtazapine and paroxetine in major depression. Am J Med Genet B Neuropsychiatr Genet. 2007; 144B(3):325-31.

68. Tzeng DS, Chien CC, Lung FW, Yang CY. MAOA gene polymorphisms and response to mirtazapine in major depression. Hum Psychopharmacol. 2009; 24(4):293-300.

69. Muller DJ, Schulze TG, Macciardi F, Ohlraun S, Gross MM, Scherk H, et al. Moclobemide response in depressed patients: association study with a functional polymorphism in the monoamine oxidase A promoter. Pharmacopsychiatry. 2002; 35(4):157-8.

70. Cusin C, Serretti A, Zanardi R, Lattuada E, Rossini $D$, Lilli R, et al. Influence of monoamine oxidase A and serotonin receptor $2 \mathrm{~A}$ polymorphisms in SSRI antidepressant activity. Int I Neuropsychopharmacol. 2002; 5(1):27-35.

71. Arias B, Fabbri C, Gressier F, Serretti A, Mitjans M, Gasto C, et al. TPH1, MAOA, serotonin receptor $2 A$ and $2 \mathrm{C}$ genes in citalopram response: possible effect in melancholic and psychotic depression. Neuropsychobiology. 2013; 67(1):41-7.

72. Tiwari AK, Zai CC, Sajeev G, Arenovich T, Muller DJ, Kennedy JL. Analysis of 34 candidate genes in bupropion and placebo remission. Int J Neuropsychopharmacol. 2013; 16(4):771-81.

73. Serretti A, Calati R, Mandelli L, De Ronchi D. Serotonin transporter gene variants and behavior: a comprehensive review. Curr Drug Targets. 2006; 7(12):1659-69.

74. Porcelli S, Fabbri C, Serretti A. Meta-analysis of serotonin transporter gene promoter polymorphism (5-HTTLPR) association with antidepressant efficacy. Eur Neuropsychopharmacol. 2012; 22(4):239-58.

75. Murphy GM Jr, Kremer C, Rodrigues HE, Schatzberg AF. Pharmacogenetics of antidepressant medication intolerance. Am J Psychiatry. 2003; 160(10):1830-5.

76. Lotrich FE, Pollock BG, Kirshner M, Ferrell RF, Reynolds lii CF. Serotonin transporter genotype interacts with paroxetine plasma levels to influence depression treatment response in geriatric patients. J Psychiatry Neurosci. 2008; 33(2):123-30.
77. Benedetti F, Barbini B, Bernasconi A, Fulgosi MC, Campori E, Colombo C, et al. Lithium overcomes the influence of 5-HTTLPR gene polymorphism on antidepressant response to sleep deprivation. J Clin Psychopharmacol. 2008; 28(2):249-51.

78. Stamm TJ, Adli M, Kirchheiner J, Smolka MN, Kaiser R, Tremblay PB, et al. Serotonin transporter gene and response to lithium augmentation in depression. Psychiatr Genet. 2008; 18(2):92-7.

79. Walderhaug E, Magnusson A, Neumeister A, Lappalainen J, Lunde H, Refsum H, et al. Interactive effects of sex and 5-HTTLPR on mood and impulsivity during tryptophan depletion in healthy people. Biol Psychiatry. 2007; 62(6):593-9.

80. Ogilvie AD, Battersby S, Bubb VJ, Fink G, Harmar AJ, Goodwim GM, et al. Polymorphism in serotonin transporter gene associated with susceptibility to major depression. Lancet. 1996; 347(9003):731-3.

81. Min W, Li T, Ma X, Li Z, Yu T, Gao D, et al. Monoamine transporter gene polymorphisms affect susceptibility to depression and predict antidepressant response. Psychopharmacology (Berl). 2009; 205(3): 409-17.

82. Wilkie MJ, Smith G, Day RK, Matthews K, Smith D, Blackwood D, et al. Polymorphisms in the SLC6A4 and HTR2A genes influence treatment outcome following antidepressant therapy. Pharmacogenomics J. 2009; 9(1):61-70.

83. Mrazek DA, Rush AJ, Biernacka JM, O'Kane DJ, Cunningham JM, Wieben ED, et al. SLC6A4 variation and citalopram response. Am J Med Genet B Neuropsychiatr Genet. 2009; 150B(3):341-51.

84. Huezo-Diaz P, Uher R, Smith R, Rietschel M, Henigsberg N, Marusic A, et al. Moderation of antidepressant response by the serotonin transporter gene. Br J Psychiatry. 2009; 195(1):30-8.

85. Dogan O, Yuksel N, Ergun MA, Yilmaz A, Ilhan MN, Karslioglu HE, et al. Serotonin transporter gene polymorphisms and sertraline response in major depression patients. Genet Test. 2008; 12(2):225-31.

86. Smits KM, Smits LJ, Schouten JS, Stelma FF, Nelemans P, Prins MH. Influence of SERTPR and STin2 in the serotonin transporter gene on the effect of selective serotonin reuptake inhibitors in depression: a systematic review. Mol Psychiatry. 2004; 9(5):433-41.

87. Popp J, Leucht S, Heres S, Steimer W. Serotonin transporter polymorphisms and side effects in antidepressant therapy - a pilot study. Pharmacogenomics. 2006; 7(2):159-66.

88. Smits K, Smits L, Peeters F, Schouten J, Janssen R, Smeets $\mathrm{H}$, et al. Serotonin transporter polymorphisms and the occurrence of adverse events during treatment with selective serotonin reuptake inhibitors. Int Clin Psychopharmacol. 2007; 22(3):137-43.

89. Kraft JB, Slager SL, McGrath PJ, Hamilton SP. Sequence analysis of the serotonin transporter and associations with antidepressant response. Biol Psychiatry. 2005; 58(5):374-81.

90. Smeraldi E, Serretti A, Artioli P, Lorenzi C, Catalano M. Serotonin transporter gene-linked polymorphic region: possible pharmacogenetic implications of rare variants. Psychiatr Genet. 2006; 16(4):153-8.

91. Baffa A, Hohoff C, Baune BT, Muller-Tidow C, Tidow N, Freitag C, et al. Norepinephrine and serotonin transporter genes: impact on treatment response in depression. Neuropsychobiology. 2010; 62(2):121-31. 
92. Kraft JB, Peters EJ, Slager SL, Jenkins GD, Reinalda MS, McGrath PJ, et al. Analysis of association between the serotonin transporter and antidepressant response in a large clinical sample. Biol Psychiatry. 2007; 61(6):734-42.

93. Maron E, Tammiste A, Kallassalu K, Eller T, Vasar V, Nutt DJ, et al. Serotonin transporter promoter region polymorphisms do not influence treatment response to escitalopram in patients with major depression. Eur Neuropsychopharmacol. 2009; 19(6):451-6.

94. Bonvicini C, Minelli A, Scassellati C, Bortolomasi $M$, Segala M, Sartori R, et al. Serotonin transporter gene polymorphisms and treatment-resistant depression. Prog Neuropsychopharmacol Biol Psychiatry. 2010; 34(6):934-9.

95. Timotijević I, Stanković Z, Todorović M, Marković SZ, Kastratović DA. Serotonergic organization of the central nervous system. Psychiatr Danub. 2012; 24(Suppl 3):S326-30.

96. Carr GV, Lucki I. The role of serotonin receptor subtypes in treating depression: a review of animal studies. Psychopharmacology (Berl). 2011; 213(2-3):265-87.

97. Shrestha S, Hirvonen J, Hines CS, Henter ID, Svenningsson P, Pike VW, et al. Serotonin-1A receptors in major depression quantified using PET: controversies, confounds, and recommendations. Neuroimage. 2012; 59(4):3243-51.

98. Porcelli S, Drago A, Fabbri C, Gibiino S, Calati R, Serretti A. Pharmacogenetics of antidepressant response. J Psychiatry Neurosci. 2011; 36(2):87113.

99. Yu YW, Tsai SJ, Liou YJ, Hong CJ, Chen TJ. Association study of two serotonin $1 \mathrm{~A}$ receptor gene polymorphisms and fluoxetine treatment response in Chinese major depressive disorders. Eur Neuropsychopharmacol. 2006; 16(7):498503.

100. McMahon FJ, Buervenich S, Charney D, Lipsky R, Rush AJ, Wilson AF, et al. Variation in the gene encoding the serotonin $2 \mathrm{~A}$ receptor is associated with outcome of antidepressant treatment. Am J Hum Genet. 2006; 78(5):804-14.

101. Wesolowska A, Nikiforuk A. Effects of the brain-penetrant and selective 5-HT6 receptor antagonist SB-399885 in animal models of anxiety and depression. Neuropharmacology. 2007; 52(5):1274-83.

102. Wu WH, Huo SJ, Cheng CY, Hong CJ, Tsai SJ. Association study of the $5-\mathrm{HT}(6)$ receptor polymorphism (C267T) and symptomatology and antidepressant response in major depressive disorders. Neuropsychobiology. 2001; 44(4):172-5.

103. Lee SH, Lee KJ, Lee HJ, Ham BJ, Ryu SH, Lee MS. Association between the 5-HT6 receptor C267T polymorphism and response to antidepressant treatment in major depressive disorder. Psychiatry Clin Neurosci. 2005; 59(2):140-5.

104. Illi A, Setälä-Soikkeli E, Viikki M, Poutanen O, Huhtala $\mathrm{H}$, Mononen N, et al. 5-HTR1A, 5-HTR2A, 5-HTR6, TPH1 and TPH2 polymorphisms and major depression. Neuroreport. 2009; 20(12):1125-8.

105. Tatsumi M, Groshan K, Blakely RD, Richelson E. Pharmacological profile of antidepressants and related compounds at human monoamine transporters. Eur J Pharmacol. 1997; 340(23):249-58.

106. Fuller RW, Hemrick-Luecke SK. Antagonism by atomoxetine of the depletion of norepinephrine and epinephrine in rat brain by alpha-methyl-m-tyro- sine. Res Commun Chem Pathol Pharmacol. 1983; 41(1):169-72.

107. Bönisch H, Brüss $M$. The norepinephrine transporter in physiology and disease. Handb Exp Pharmacol. 2006; (175):485-524.

108. Zill P, Engel R, Baghai TC, Juckel G, Frodl T, Muller-Siecheneder F, et al. Identification of a naturally occurring polymorphism in the promoter region of the norepinephrine transporter and analysis in major depression.

Neuropsychopharmacology. 2002; 26(4):489-93.

109. Yoshida K, Takahashi H, Higuchi H, Kamata M, Ito $\mathrm{K}$, Sato K, et al. Prediction of antidepressant response to milnacipran by norepinephrine transporter gene polymorphisms. Am J Psychiatry. 2004; 161(9):1575-80.

110. Kim H, Lim SW, Kim S, Kim JW, Chang YH, Carroll $B J$, et al. Monoamine transporter gene polymorphisms and antidepressant response in Koreans with late-life depression. JAMA. 2006; 296(13):1609-18.

111. Houston JP, Lau K, Aris V, Liu W, Fijal BA, Heinloth AN, et al. Association of common variations in the norepinephrine transporter gene with response to olanzapine-fluoxetine combination versus continued-fluoxetine treatment in patients with treatment-resistant depression: a candidate gene analysis. J Clin Psychiatry. 2012; 73(6):878-85.

112. Xu Z, Zhang Z, Shi Y, Pu M, Yuan Y, Zhang X, et al. Influence and interaction of genetic polymorphisms in catecholamine neurotransmitter systems and early life stress on antidepressant drug response. I Affect Disord. 2011; 133(12):165-73.

113. Nemeroff CB, Vale WW. The neurobiology of depression: inroads to treatment and new drug discovery. J Clin Psychiatry. 2005; 66 Suppl 7:5-13.

114. Miniati M, Rucci P, Benvenuti A, Frank E, Buttenfield J, Giorgi G, et al. Clinical characteristics and treatment outcome of depression in patients with and without a history of emotional and physical abuse. J Psychiatr Res. 2010; 44(5):302-9.

115. Zill P, Baghai TC, Engel R, Zwanzger P, Schule C, Minov C, et al. Beta-1-adrenergic receptor gene in major depression: influence on antidepressant treatment response. Am J Med Genet B Neuropsychiatr Genet. 2003; 120B(1):85-9.

116. Crowley JJ, Lipsky RH, Lucki I, Berrettini WH. Variation in the genes encoding vesicular monoamine transporter 2 and beta- 1 adrenergic receptor and antidepressant treatment outcome. Psychiatr Genet. 2008; 18(5):248-51.

117. Perroud N, Aitchison KJ, Uher R, Smith R, Huezo-Diaz P, Marusic A, et al. Genetic predictors of increase in suicidal ideation during antidepressant treatment in the GENDEP project. Neuropsychopharmacology. 2009; 34(12):2517-28.

118. Smith TD, Kuczenski R, George-Friedman K, Malley JD, Foote SL. In vivo microdialysis assessment of extracellular serotonin and dopamine levels in awake monkeys during sustained fluoxetine administration. Synapse. 2000; 38(4):460-70.

119. Kugaya A, Seneca NM, Snyder PJ, Williams SA, Malison RT, Baldwin RM, et al. Changes in human in vivo serotonin and dopamine transporter availabilities during chronic antidepressant administration. Neuropsychopharmacology. 2003; 28(2):413-20.

120. Ichikawa J, Meltzer HY. Effect of antidepressants on striatal and accumbens extracellular dopamine levels. Eur J Pharmacol. 1995; 281(3):255-61. 
121. Georgieva L, Dimitrova A, Nikolov I, Koleva S, Tsvetkova R, Owen MJ, et al. Dopamine transporter gene (DAT1) VNTR polymorphism in major psychiatric disorders: family-based association study in the Bulgarian population. Acta Psychiatr Scand. 2002; 105(5):396-9.

122. Greenwood TA, Alexander M, Keck PE, McElroy S, Sadovnick AD, Remick RA, et al. Evidence for linkage disequilibrium between the dopamine transporter and bipolar disorder. Am J Med Genet. 2001; 105(2):145-51.

123. Waldman ID, Robinson BF, Feigon SA. Linkage disequilibrium between the dopamine transporter gene (DAT1) and bipolar disorder: extending the transmission disequilibrium test (TDT) to examine genetic heterogeneity. Genet Epidemiol. 1997; 14(6):699-704.

124. Mill J, Asherson P, Browes C, D'Souza U, Craig I. Expression of the dopamine transporter gene is regulated by the 3' UTR VNTR: Evidence from brain and lymphocytes using quantitative RT-PCR. Am J Med Genet. 2002; 114(8):975-9.

125. Kirchheiner J, Nickchen K, Sasse J, Bauer M, Roots I, Brockmoller J. A 40-basepair VNTR polymorphism in the dopamine transporter (DAT1) gene and the rapid response to antidepressant treatment. Pharmacogenomics J. 2007; 7:48-55.

126. Lavretsky H, Siddarth P, Kumar A, Reynolds CF. The effects of the dopamine and serotonin transporter polymorphisms on clinical features and treatment response in geriatric depression: a pilot study. Int I Geriatr Psychiatry. 2008; 23:55-9.

127. Beaulieu JM, Gainetdinov RR. The physiology, signaling, and pharmacology of dopamine receptors. Pharmacol Rev. 2011; 63(1):182-217.

128. Dziedzicka-Wasylewska M, Solich J. Neuronal cell lines transfected with the dopamine D2 receptor gene promoter as a model for studying the effects of antidepressant drugs. Brain Res Mol Brain Res. 2004; 128(1):75-82.

129. Perlis RH, Adams DH, Fijal B, Sutton VK, Farmen $M$, Breier A, et al. Genetic association study of treatment response with olanzapine/fluoxetine combination or lamotrigine in bipolar I depression. J Clin Psychiatry. 2010; 71:599-605.

130. Serretti A, Zanardi R, Cusin C, Rossini D, Lilli R, Lorenzi $C$, et al. No association between dopamine D2 and D4 receptor gene variants and antidepressant activity of two selective serotonin reuptake inhibitors. Psychiatry Res. 2001; 104:195-203.

131. Kugaya A, Sanacora G. Beyond monoamines: glutamatergic function in mood disorders. CNS Spectr. 2005; 10(10):808-19.

132. Drago A, Crisafulli C, Sidoti A, Serretti A. The molecular interaction between the glutamatergic, noradrenergic, dopaminergic and serotoninergic systems informs a detailed genetic perspective on depressive phenotypes. Prog Neurobiol. 2011; 94(4):418-60.

133. Paddock S, Laje G, Charney D, Rush AJ, Wilson AF, Sorant AJ, et al. Association of GRIK4 with outcome of antidepressant treatment in the STAR ${ }^{\star}$ cohort. Am J Psychiatry. 2007; 164(8):1181-8.

134. Horstmann S, Lucae S, Menke A, Hennings JM, Ising M, Roeske D, et al. Polymorphisms in GRIK4, HTR2A, and FKBP5 show interactive effects in predicting remission to antidepressant treatment. Neuropsychopharmacology. 2010; 35(3):727-40.

135. Serretti A, Chiesa A, Crisafulli C, Massat I, Linotte $S$, Calati $R$, et al. Failure to replicate influence of
GRIK4 and GNB3 polymorphisms on treatment outcome in major depression. Neuropsychobiology. 2012; 65(2):70-5

136. Fabbri C, Drago A, Serretti A. Early antidepressant efficacy modulation by glutamatergic gene variants in the STAR*D. Eur Neuropsychopharmacol. 2013; 23(7):612-21.

137. Hamm HE. The many faces of $G$ protein signaling. J Biol Chem. 1998; 273(2):669-72.

138. Wilkie MJ, Smith D, Reid IC, Day RK, Matthews K, Wolf $\mathrm{CR}$, et al. A splice site polymorphism in the G-protein beta subunit influences antidepressant efficacy in depression. Pharmacogenet Genomics. 2007; 17(3): 207-15.

139. Keers R, Bonvicini C, Scassellati $C$, Uher R, Placentino A, Giovannini C, et al. Variation in GNB3 predicts response and adverse reactions to antidepressants. J Psychopharmacol. 2011; 25(7):867-74.

140. Serretti A, Lorenzi C, Cusin C, Zanardi R, Lattuada $E$, Rossini $D$, et al. SSRIs antidepressant activity is influenced by $\mathrm{G}$ beta 3 variants. Eur Neuropsychopharmacol. 2003; 13(2):117-22.

141. Lin E, Chen PS, Chang HH, Gean PW, Tsai HC, Yang YK, et al. Interaction of serotonin-related genes affects short-term antidepressant response in major depressive disorder. Prog Neuropsychopharmacol Biol Psychiatry. 2009; 33(7):1167-72.

142. Kang RH, Hahn SW, Choi MJ, Lee MS. Relationship between $\mathrm{G}$-protein beta-3 subunit C825T polymorphism and mirtazapine responses in Korean patients with major depression. Neuropsychobiology. 2007; 56(1):1-5.

143. Grimes CA, Jope RS. The multifaceted roles of glycogen synthase kinase 3 beta in cellular signaling. Prog Neurobiol. 2001; 65(4):391-426.

144. Beaulieu JM, Gainetdinov RR, Caron MG. Akt/ GSK3 signaling in the action of psychotropic drugs. Annu Rev Pharmacol Toxicol. 2009; 49:327-47.

145. Beaulieu JM, Zhang X, Rodriguiz RM, Sotnikova TD, Cools MJ, Wetsel WC, et al. Role of GSK3 beta in behavioral abnormalities induced by serotonin deficiency. Proc Natl Acad Sci U S A. 2008; 105(4):1333-8.

146. Kwok JB, Hallupp M, Loy CT, Chan DK, Woo J, Mellick GD, et al. GSK3B polymorphisms alter transcription and splicing in Parkinson's disease. Ann Neurol. 2005; 58(6):829-39.

147. Benedetti F, Dallaspezia S, Lorenzi C, Pirovano A Radaelli D, Locatelli C, et al. Gene-gene interaction of glycogen synthase kinase 3-beta and serotonin transporter on human antidepressant response to sleep deprivation. J Affect Disord. 2012; 136(3):514-9.

148. Adli M, Hollinde DL, Stamm T, Wiethoff K, Tsahuridu M, Kirchheiner J, et al. Response to lithium augmentation in depression is associated with the glycogen synthase kinase 3-beta-50T/C single nucleotide polymorphism. Biol Psychiatry. 2007; 62(11):1295-302.

149. Tsai SJ, Liou YJ, Hong CJ, Yu YW, Chen TJ. Glycogen synthase kinase-3beta gene is associated with antidepressant treatment response in Chinese major depressive disorder. Pharmacogenomics J. 2008; 8(6):384-90.

150. Serretti A, Chiesa A, Calati R, Massat I, Linotte S, Kasper S, et al. A preliminary investigation of the influence of CREB1 gene on treatment resistance in major depression. J Affect Disord. 2011; 128(1-2): 56-63. 
151. Crisafulli C, Shim DS, Andrisano C, Pae CU, Chiesa A, Han C, et al. Case-control association study of 14 variants of CREB1, CREBBP and CREM on diagnosis and treatment outcome in major depressive disorder and bipolar disorder. Psychiatry Res. 2012; 198(1):39-46.

152. Seymour PA, Schmidt AW, Schulz DW. The pharmacology of CP-154,526, a non-peptide antagonist of the CRH1 receptor: a review. CNS Drug Rev. 2003; 9(1):57-96.

153. Overstreet DH, Griebel G. Antidepressant-like effects of CRF1 receptor antagonist SSR125543 in an animal model of depression. Eur J Pharmacol. 2004; 497(1):49-53.

154. Kehne JH. The CRF1 receptor, a novel target for the treatment of depression, anxiety, and stress-related disorders. CNS Neurol Disord Drug Targets. 2007; 6(3):163-82.

155. Fabbri C, Di Girolamo G, Serretti A. Pharmacogenetics of antidepressant drugs: An update after almost 20 years of research. Am J Med Genet B Neuropsychiatr Genet. 2013; $162 \mathrm{~B}(6): 487-520$.

156. Licinio J, O'Kirwan F, Irizarry K, Merriman B, Thakur S, Jepson R, et al. Association of a corticotropin-releasing hormone receptor 1 haplotype and antidepressant treatment response in Mexican-Americans. Mol Psychiatry. 2004; 9(12):1075-82.

157. Liu Z, Zhu F, Wang G, Xiao Z, Tang J, Liu W, et al. Association study of corticotropin-releasing hormone receptor 1 gene polymorphisms and antidepressant response in major depressive disorders. Neurosci Lett. 2007; 414(2):155-8.

158. Papiol S, Arias B, Gasto C, Gutierrez B, Catalan R, Fananas L. Genetic variability at HPA axis in major depression and clinical response to antidepressant treatment. J Affect Disord. 2007; 104(13):83-90.

159. Binder EB, Owens MJ, Liu W, Deveau TC, Rush AJ, Trivedi MH, et al. Association of polymorphisms in genes regulating the corticotropin-releasing factor system with antidepressant treatment response. Arch Gen Psychiatry. 2010; 67(4):36979.

160. Perlis RH, Fijal B, Dharia S, Houston JP. Pharmacogenetic investigation of response to duloxetine treatment in generalized anxiety disorder Pharmacogenomics J. 2013; 13(3):280-5.

161. Wong ML, Dong C, Maestre-Mesa J, Licinio J. Polymorphisms in inflammation-related genes are associated with susceptibility to major depression and antidepressant response. Mol Psychiatry. 2008; 13(8):800-12.

162. Keers R, Uher R. Gene-environment interaction in major depression and antidepressant treatment response. Curr Psychiatry Rep. 2012; 14(2):12937.

163. van Rossum EF, Binder EB, Majer M, Koper JW, Ising M, Modell S, et al. Polymorphisms of the glucocorticoid receptor gene and major depression. Biol Psychiatry. 2006; 59(8):681-8.

164. Uher R, Huezo-Diaz P, Perroud N, Smith R, Rietschel M, Mors O, et al. Genetic predictors of response to antidepressants in the GENDEP project. Pharmacogenomics J. 2009; 9(4):225-33.

165. Cattaneo A, Gennarelli M, Uher R, Breen G, Farmer A, Aitchison KJ, et al. Candidate genes expression profile associated with antidepressants response in the GENDEP study: differentiating between baseline 'predictors' and longitudinal 'targets'. Neuropsychopharmacology. 2013; 38(3):377-85.
166. Millan MJ. Multi-target strategies for the improved treatment of depressive states: Conceptual foundations and neuronal substrates, drug discovery and therapeutic application. Pharmacol Ther. 2006; 110(2):135-370.

167. Yu H, Chen ZY. The role of BDNF in depression on the basis of its location in the neural circuitry. Acta Pharmacol Sin. 2011; 32(1):3-11.

168. Castren E, Rantamaki T. The role of BDNF and its receptors in depression and antidepressant drug action: Reactivation of developmental plasticity. Dev Neurobiol. 2010; 70(5):289-97.

169. Jacobsen JP, Mork A. The effect of escitalopram, desipramine, electroconvulsive seizures and lithium on brain-derived neurotrophic factor mRNA and protein expression in the rat brain and the correlation to 5-HT and 5-HIAA levels. Brain Res. 2004; 1024(1-2):183-92.

170. Egan MF, Kojima M, Callicott JH, Goldberg TE, Kolachana BS, Bertolino A, et al. The BDNF val66met polymorphism affects activity-dependent secretion of BDNF and human memory and hippocampal function. Cell. 2003; 112(2):257-69.

171. Tsai SJ, Cheng CY, Yu YW, Chen TJ, Hong CJ. Association study of a brain-derived neurotrophic-factor genetic polymorphism and major depressive disorders, symptomatology, and antidepressant response. Am J Med Genet B Neuropsychiatr Genet. 2003; 123B(1): 19-22.

172. Yoshida K, Higuchi H, Kamata M, Takahashi H, Inoue K, Suzuki T, et al. The G196A polymorphism of the brain-derived neurotrophic factor gene and the antidepressant effect of milnacipran and fluvoxamine. J Psychopharmacol. 2007; 21(6):650-6.

173. Zou YF, Wang Y, Liu P, Feng XL, Wang BY, Zang TH, et al. Association of BDNF Val66Met polymorphism with both baseline HRQOL scores and improvement in HRQOL scores in Chinese major depressive patients treated with fluoxetine. Hum Psychopharmacol. 2010; 25(2):145-52.

174. Choi MJ, Kang RH, Lim SW, Oh KS, Lee MS. Brain-derived neurotrophic factor gene polymorphism (Val66Met) and citalopram response in major depressive disorder. Brain Res. 2006; 1118(1):176-82

175. Alexopoulos GS, Glatt CE, Hoptman MJ, Kanellopoulos D, Murphy CF, Kelly RE Jr, et al. BDNF val66met polymorphism, white matter abnormalities and remission of geriatric depression. J Affect Disord. 2010; 125(1-3):262-8.

176. Taylor WD, McQuoid DR, Ashley-Koch A, MacFall JR, Bridgers J, Krishnan RR, et al. BDNF Val66Met genotype and 6-month remission rates in late-life depression. Pharmacogenomics J. 2011; 11(2):146-54.

177. Kocabas NA, Antonijevic I, Faghel C, Forray C, Kasper S, Lecrubier Y, et al. Brain-derived neurotrophic factor gene polymorphisms: influence on treatment response phenotypes of major depressive disorder. Int Clin Psychopharmacol. 2011; 26(1):1-10.

178. Chi MH, Chang HH, Lee SY, Lee IH, Gean PW, Yang YK, et al. Brain derived neurotrophic factor gene polymorphism (Val66Met) and short-term antidepressant response in major depressive disorder. J Affect Disord. 2010; 126(3):430-5.

179. Domschke K, Lawford B, Laje G, Berger K, Young $\mathrm{R}$, Morris $\mathrm{P}$, et al. Brain-derived neurotrophic factor (BDNF) gene: no major impact on antidepressant treatment response. Int Neuropsychopharmacol. 2010; 13(1):93-101. 
180. Kang RH, Chang HS, Wong ML, Choi MJ, Park JY, Lee HY, et al. Brain-derived neurotrophic factor gene polymorphisms and mirtazapine responses in Koreans with major depression. J Psychopharmacol. 2010; 24(12):1755-63.

181. Musil R, Zill P, Seemuller F, Bondy B, Obermeier $M$, Spellmann I, et al. No influence of brain-derived neurotrophic factor (BDNF) polymorphisms on treatment response in a naturalistic sample of patients with major depression. Eur Arch Psychiatry and Clin Neurosci. 2013; 263(5):405-12.

182. Gratacos M, Soria V, Urretavizcaya M, Gonzalez $J R$, Crespo JM, Bayes M, et al. A brain-derived neurotrophic factor (BDNF) haplotype is associated with antidepressant treatment outcome in mood disorders. Pharmacogenomics J. 2008; 8(2):101-12.

183. Mandelli L, Mazza M, Martinotti G, Tavian D, Colombo E, Missaglia S, et al. Further evidence supporting the influence of brain-derived neurotrophic factor on the outcome of bipolar depression: independent effect of brain-derived neurotrophic factor and harm avoidance. J Psychopharmacol. 2010; 24(12):1747-54.

184. Dong C, Wong ML, Licinio J. Sequence variations of ABCB1, SLC6A2, SLC6A3, SLC6A4, CREB1, CRHR1 and NTRK2: association with major depression and antidepressant response in Mexican-Americans. Mol Psychiatry. 2009; 14(12):1105-18

185. Perroud N. Suicidal ideation during antidepressant treatment: do genetic predictors exist? CNS Drugs. 2011; 25(6):459-71

186. Perroud N, Uher R, Ng MY, Guipponi M, Hauser J, Henigsberg N, et al. Genome-wide association study of increasing suicidal ideation during antidepressant treatment in the GENDEP project. Pharmacogenomics J. 2011; 12(1):68-77.

187. Sun Y, Jin K, Xie L, Childs J, Mao XO, Logvinova A, et al. VEGF-induced neuroprotection, neurogenesis, and angiogenesis after focal cerebral ischemia. J Clin Invest. 2003; 111(12):1843-51.

188. Zill P, Baghai TC, Engel R, Zwanzger P, Schule C, Eser $D$, et al. The dysbindin gene in major depression: an association study. Am J Med Genet B Neuropsychiatr Genet. 2004; 129B(1):55-8.

189. Kocabas NA, Antonijevic I, Faghel C, Forray C, Kasper S, Lecrubier Y, et al. Dysbindin gene (DTNBP1) in major depressive disorder (MDD) patients: lack of association with clinical phenotypes. World J Biol Psychiatry. 2010; 11(8):985-90.

190. Arias B, Serretti A, Mandelli L, Gasto C, Catalan R, Ronchi DD, et al. Dysbindin gene (DTNBP1) in major depression: association with clinical response to selective serotonin reuptake inhibitors. Pharmacogenet Genomics. 2009; 19(2):121-8.

191. Pae CU, Serretti A, Mandelli L, De Ronchi D, Patkar AA, Jun TY, et al. Dysbindin associated with selective serotonin reuptake inhibitor antidepressant efficacy. Pharmacogenet Genomics. 2007; 17(1):69-75.

192. Bondy B, Baghai TC, Zill P, Schule C, Eser D, Deiml $\mathrm{T}$, et al. Genetic variants in the angiotensin I-converting-enzyme (ACE) and angiotensin II receptor (AT1) gene and clinical outcome in depression. Prog Neuropsychopharmacol Biol Psychiatry. 2005; 29(6):1094-9.

193. Baghai TC, Schule C, Zill P, Deiml T, Eser D, Zwanzger P, et al. The angiotensin I converting enzyme insertion/deletion polymorphism influences therapeutic outcome in major depressed women, but not in men. Neurosci Lett. 2004; 363(1):38-42.

194. Kishi T, Yoshimura R, Fukuo Y, Kitajima T, Okochi $\mathrm{T}$, Matsunaga S, et al. The CLOCK gene and mood disorders: a case-control study and meta-analysis. Chronobiol Int. 2011; 28(9):825-33.

195. Kishi T, Kitajima T, Ikeda M, Yamanouchi Y, Kinoshita Y, Kawashima K, et al. CLOCK may predict the response to fluvoxamine treatment in Japanese major depressive disorder patients. Neuromolecular Med. 2009; 11(2):53-7.

196. Shen X, Carlborg O. Beware of risk for increased false positive rates in genome-wide association studies for phenotypic variability. Front Genet. 2013; 4:93.

197. Craddock N, Kendler K, Neale M, Nurnberger J, Purcell S, Rietschel M, et al. Dissecting the phenotype in genome-wide association studies of psychiatric illness. Br J Psychiatry. 2009; 195(2):97-9.

198. Garriock HA, Hamilton SP. Genetic studies of drug response and side effects in the STAR*D study, part 1. J Clin Psychiatry. 2009; 70(8):1186-7.

199. Laje G, Perlis RH, Rush AJ, McMahon FJ. Pharmacogenetics studies in STAR ${ }^{\star}$ : strengths, limitations, and results. Psychiatr Serv. 2009; 60(11):1446-57.

200. Laje G, McMahon FJ. Genome-wide association studies of antidepressant outcome: a brief review. Prog Neuropsychopharmacol Biol Psychiatry. 2010; 35(7):1553-7.

201. McCarthy MI, Hirschhorn JN. Genome-wide association studies: past, present and future. Hum Mol Genet. 2008; 17(R2):R100-1.

202. Holmans P. Statistical methods for pathway analysis of genome-wide data for association with complex genetic traits. Adv Genet. 2010; 72:141-79.

203. Jia P, Wang L, Meltzer HY, Zhao Z. Pathway-based analysis of GWAS datasets: effective but caution required. Int J Neuropsychopharmacol. 2011; 14(4):567-72.

204. Yang J, Lee SH, Goddard ME, Visscher PM. GCTA: a tool for genome-wide complex trait analysis. Am J Hum Genet. 2011; 88(1):76-82.

205. Tansey KE, Guipponi M, Hu X, Domenici E, Lewis $\mathrm{G}$, Malafosse A, et al. Contribution of common genetic variants to antidepressant response. Biol Psychiatry. 2013; 73(7):679-82. 


\section{Farmakogenetika lekova protiv depresije: najnovija saznanja}

Concetta Crisafulli ${ }^{1}$, Antonio Drago ${ }^{2,3}$, Marco Calabrò ${ }^{1,4}$, Antonina Sidoti ${ }^{1}$, Alessandro Serretti ${ }^{2}$, Edoardo Spina ${ }^{4}$

${ }^{1}$ Katedra za biomedicinsku nauku i morfološke i funkcionalne slike, Univerzitet u Mesini, Mesina, Italija;

${ }^{2}$ Katedra za biomedicinske i neuromotorne nauke - DIBINEM, Univerzitet u Bolonji, Bolonja, Italija;

${ }^{3}$ I.R.C.C.S. "San Giovanni di Dio”, Fatebenefratelli, Breša, Italija;

${ }^{4}$ Katedra za kliničku i eksperimentalnu medicinu, Univerzitet u Mesini, Mesina, Italija

\section{KRATAK SADRŽAJ}

Farmakološko lečenje depresivnih oboljenja odlikuje se time što postoji loša predvidljivost individualnog odgovora. Poslednjih godina sve veći broj dokaza je pokazao da genetski faktori igraju ključnu ulogu u utvrđivanju razlika u ishodu lečenja antidepresivnim lekovima. Vrše se brojne farmakogenetičke studije o ovim lekovima i otkrivene su genske varijacije na nivou enzima koji metabolišu lekove, transportera leka i ciljnih mesta za dejstvo leka, koji najverovatnije utiču na klinički odgovor. Nadamo se da farmakogenetika može da stvori osnovu za individualizovanu farmakoterapiju depresivnih oboljenja, kako bi se maksimalno povećala mogućnost za dobijanje povoljnog odgovora i smanjio rizik od nastanka neželjenih reakcija na lek. U ovom članku dat je kritički pregled glavnih nalaza u vezi s farmakogenetikom gena uključenih u farmakokinetiku i farmakodinamiku antidepresivnih lekova.

Ključne reči: farmakogenetika; antidepresivi; gen; depresija 